\title{
SHORT REPORT: HERPES-LIKE DNA SEQUENCES IN AFRICAN-ENDEMIC AND ACQUIRED IMMUNODEFICIENCY SYNDROME-ASSOCIATED KAPOSI'S SARCOMA
}

\author{
HIDEAKI ETO, NOAH OMOLO KAMIDIGO, KAORU MURAKAMI-MORI, \\ SHUII NAKAMURA, KAN TORIYAMA, AND HIDEYO ITAKURA \\ Department of Pathology, Institute of Tropical Medicine, Nagasaki University, Nagasaki, Japan; \\ Histology Department, Rift Valley Provincial Hospital, Nakuru, Kenya; Institute of Molecular \\ Medicine and Technology, Huntington Memorial Hospital, Pasadena, Califomia
}

\begin{abstract}
Recently, the unique nucleic acid closely related to the herpes-like sequences has been found in acquired immunodeficiency syndrome (AIDS)-associated Kaposi's sarcoma (KS). We have confirmed the presence of herpeslike DNA sequences in six cases of AIDS-associated KS and three of the nine cases of African-endemic KS in adults, but not in eight cases of $\mathrm{KS}$ in children from the same area. These sequences were seen in a histologically early stage of KS. Our results suggest that herpes-like DNA sequences may play an important role in the pathogenesis of AIDS-associated KS.
\end{abstract}

Kaposi's sarcoma (KS) has been observed frequently in patients with human immunodeficiency virus (HIV) infection, especially young homosexuals in western countries, but the sarcoma was endemic in equatorial Africa before HIV was known in this area. However, several investigations have failed to establish an exact etiology for this disease. Many studies have speculated that $\mathrm{KS}$ is associated with cytomegalovirus, human herpes virus 6 , and HIV.1.2 Recently, Chang and others identified DNA sequences closely related to gamma-herpesviruses in acquired immunodeficiency syndrome (AIDS)-associated $\mathrm{KS}$ in the United States. ${ }^{3}$ These unique sequences are also seen in KS without HIV infection. ${ }^{4-6}$ We report the presence of the same herpesvirus-like nucleic acid in biopsy specimens from African-endemic and AIDS-associated KS in the United States using a polymerase chain reaction (PCR) method.

Twenty-three cases of KS were investigated. Seventeen were endemic African, nine were from adult patients; of these, eight were HIV-negative and one was HIV-positive. Eight other cases were in children without HIV infection. All specimens were collected at the Nakuru and Kisumu Provincial Hospitals of western Kenya. The remaining six cases were AIDS-associated KS in homosexual patients whose specimens were collected at the University of Southern California (Los Angeles, CA) in the United States. Four pathologists (HE, NK, KT, and HI) examined all specimens independently and confirmed a histologic diagnosis of KS. Paraffin-embedded sections $(5-\mu \mathrm{m})$ of each tissue, including tumorous lesions and normal areas, were used for the PCR. After the tissue sections were deparaffinized and dehydrated, they were digested in $50 \mu l$ of lysis buffer (400 $\mu \mathrm{g} / \mathrm{ml}$ of proteinase $\mathrm{K}, 4 \mathrm{mM}$ EDTA, $100 \mathrm{mM}$ Tris- $\mathrm{HCl}$ ) for $4 \mathrm{hr}$ at $55^{\circ} \mathrm{C}$. One microliter of each digest was used for the PCR. The primers 5'-AGCCGAAAGGATTCCACCATT-3' and 5'-TCCGTGTTGTCTACGTCCAGA-3' were used in the PCR, and products were separated by electrophoresis on a $3.0 \%$ agarose gel and stained with ethidium bromide. Chang and others published nucleotide sequences of the 1,853-base pair flanking region that includes KS330 Bam derived from a KS lesion genomic library. ${ }^{3}$ Herpes-like DNA sequences are located from basepairs 987 to 1219. The primer set extends from base pairs 987 to 1006 and 1200 to
1219. Therefore, the amplified band should be 233 basepairs. As a positive amplification control, primers for the beta-globin genomic sequence were also simultaneously present during the amplification. ${ }^{7}$

Three of the nine cases of African-endemic KS in adults, two that were HIV-negative and one that was HIV-positive, were positive for herpesvirus-like DNA sequences. None of the eight case of African-endemic KS in children were positive for these sequences. All six cases of AIDS-associated KS were positive for herpes-like DNA. Histologically, seven of the nine cases that were positive for these sequences showed the granulation tissue-like growth pattern. All herpes-like DNA-negative cases showed the angioma/angiosarcoma and spindle cell/fibrosarcoma types (Table 1).

Kaposi's sarcoma is broadly classified into four categories: classic (European) type, African-endemic type, AIDSassociated type, and the type with other immunodeficiencies. The clinical manifestations of these types are different. Furthermore, African-endemic KS is epidemiologically characterized by its occurrence in two age peaks: one in early childhood between two and three years of age and the other in middle to advanced age. Clinical manifestations are quite different. Adult KS usually affects the skin of lower extremities, has a long clinical history, is spontaneously regressive, and is not fatal. On the other hand, childhood KS tends to involve mainly the lymph nodes and shows a more rapidly fatal clinical course. ${ }^{8-10}$ Histologically, $\mathrm{KS}$ is divided into three types: granulation tissue type, angioma/angiosarcoma type, and spindle cell/fibrosarcoma type. The granulation tissue type is usually an early stage of the disease and the others are advanced stages. ${ }^{10}$

In our study, herpesvirus-like DNA sequences were seen in all cases of AIDS-associated KS and in two of the HIVnegative African-endemic KS cases in adults. This result is consistent with previous reports; ${ }^{4-6}$ however, our investigation showed a difference in childhood $\mathrm{KS}$, in which the presence of herpesvirus-like DNA sequences was not seen.

In conclusion, we did not prove whether the presence of herpes-like DNA sequences was a reflection of viral infection of KS tissue or the expression of a viral-neoplasm relationship. However, our results suggest that these sequences 
TABle 1

Herpes-like DNA sequences in Kaposi's sarcoma (KS)*

\begin{tabular}{|c|c|c|c|c|c|c|}
\hline Case & $\underset{\text { (years) }}{\text { Age }}$ & Sex & Location & HIV & $\begin{array}{c}\text { Herpes- } \\
\text { like } \\
\text { DNA }\end{array}$ & $\begin{array}{l}\text { Histo- } \\
\text { logic } \\
\text { type }\end{array}$ \\
\hline
\end{tabular}

\begin{tabular}{|c|c|c|c|c|c|c|}
\hline \multicolumn{7}{|c|}{ African-endemic KS of adults } \\
\hline 1 & 57 & $\mathbf{M}$ & Skin (scrotum) & - & - & $\mathbf{S}$ \\
\hline 2 & 18 & $\mathbf{M}$ & Skin (leg) & - & - & $\mathbf{S}$ \\
\hline 3 & 80 & $\mathbf{M}$ & Skin (foot) & - & - & $\mathbf{S}$ \\
\hline 4 & 40 & $\mathbf{M}$ & Skin (leg) & - & - & $\mathbf{A}$ \\
\hline 5 & 27 & $\mathbf{M}$ & Tonsil & - & + & $\mathbf{G}$ \\
\hline 6 & 26 & $\mathbf{M}$ & LN (neck) & - & + & $\mathbf{S}$ \\
\hline 7 & 56 & $\mathbf{M}$ & Skin (foot) & - & - & $\mathbf{s}$ \\
\hline 8 & 52 & $\mathbf{M}$ & Skin (knee) & - & - & $\mathbf{S}$ \\
\hline 9 & 30 & $\mathbf{M}$ & LN (arm) & + & + & $\mathbf{S}$ \\
\hline \multicolumn{7}{|c|}{ African-endemic KS of childhood } \\
\hline 1 & 2 & $\mathbf{M}$ & LN (neck) & - & - & $\mathbf{S}$ \\
\hline 2 & 3 & $\mathbf{M}$ & LN (neck) & - & - & $\mathbf{S}$ \\
\hline 3 & 3 & $\mathbf{M}$ & LN (neck) & - & - & $\mathbf{S}$ \\
\hline 4 & 4 & $\mathbf{M}$ & LN (neck) & - & - & $\mathbf{A}$ \\
\hline 5 & 3 & $\mathbf{M}$ & LN (neck) & - & - & $\mathbf{S}$ \\
\hline 6 & 2 & $\mathbf{F}$ & LN (neck) & - & - & $\mathbf{S}$ \\
\hline 7 & 3 & $\mathbf{F}$ & LN (neck) & - & - & $\mathbf{S}$ \\
\hline 8 & 3 & $\mathbf{M}$ & LN (neck) & - & - & $\mathbf{A}$ \\
\hline \multicolumn{7}{|c|}{ AIDS-associated KS } \\
\hline 1 & 47 & $\mathbf{M}$ & Skin (leg) & + & + & G \\
\hline 2 & 33 & $\mathbf{M}$ & Skin (thigh) & + & + & $\mathbf{G}$ \\
\hline 3 & 30 & $\mathbf{M}$ & Skin (arm) & + & + & G \\
\hline 4 & 34 & $\mathbf{M}$ & Skin (arm) & + & + & $\mathbf{G}$ \\
\hline 5 & 27 & $\mathbf{M}$ & Skin (thigh) & + & + & G \\
\hline 6 & 33 & $\mathbf{M}$ & Skin (arm) & + & + & G \\
\hline
\end{tabular}

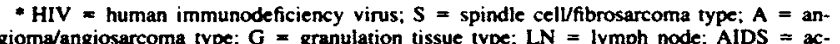
quired immunodeficiency syndrome.

may play an important role in the pathogenesis of AIDSassociated KS and are present in African-endemic KS of the adult but not in endemic $\mathrm{KS}$ of childhood.

Acknowledgment: We thank Dr. Alexandra M. Levine (Hematology Division, University of Southern California) for providing study materials.

Authors' addresses: Hideaki Eto, Kan Toriyama, and Hideyo Itakura,
Department of Pathology, Institute of Tropical Medicine, Nagasaki University, 1-12-4 Sakamoto, Nagasaki 852, Japan. Noah Omolo Kamidigo, Histology Department, Rift Valley Provincial Hospital, PO Box 71, Nakuru, Kenya. Kaoru Murakami-Mori and Shuji Nakamura, Institute of Molecular Medicine and Technology, Huntington Memorial Hospital, 744 Fairmont Avenue, Pasadena, CA 91105.

Reprint requests: Hideaki Eto, Department of Pathology, Institute of Tropical Medicine, Nagasaki University, 1-12-4 Sakamoto, Nagasaki 852, Japan.

\section{REFERENCES}

1. Craighead J, Moore A, Grossman H, Ershler W, Frattini U, Saxinger C, Hess U, Ngowi F, 1988. Pathogenic role of HIV infection in Kaposi's sarcoma of equatorial West Africa. Arch Pathol Lab Med 112: 259-265.

2. Kempf W, Adams V, Pfaltz M, Briner J. Schmid M, Moos R, Hassam S, 1995. Human herpesvirus type 6 and cytomegalovirus in AIDS-associated Kaposi's sarcoma: no evidence for etiological association. Hum Pathol 26: 914-919.

3. Chang Y, Cesarman E, Pessin MS, Lee F, Culpepper J, Knowles DM. Moore PS, 1994. Identification of herpesvirus-like DNA sequences in AIDS-associated Kaposi's sarcoma. Science 266: $1865-1869$.

4. Su IJ, Hsu YS, Chang YC, Wang IW, 1995. Herpesvirus-like DNA sequences in Kaposi's sarcoma from AIDS and nonAIDS patients in Taiwan. Lancet 345: 722-723.

5. Huang YQ, Li JJ, Kaplan MH, Poiesz B, Katabira E, Zhang WC, Feiner D, Friedman-Kien AE, 1995. Human herpesvirus-like nucleic acid in various forms of Kaposi's sarcoma. Lancet 345: 759-761.

6. Dupin N, Grandadam M, Calvez V, Gorin I, Aubin J-P, Havard $S$, Lamy F, Leibowitch M, Huraux J-M, Escande JP, Agut H, 1995. Herpes virus-like DNA sequences in patients with Mediterranean Kaposi's sarcoma. Lancet 345: 761-762.

7. Saiki RK, Scharf S, Faloona F, Mullis KB, Horn GT, Ehrlich HA, Arnheim N, 1985. enzymatic amplification of beta-globin genomic sequences and restriction analysis for diagnosis of sickle cell anemia. Science 230: 1350-1354.

8. Lulat AGMI, 1989. African Kaposi's sarcoma. Trans $R$ Soc Trop Med Hyg 83: 1-4.

9. Slavin G, Cameron HMcD, Forbes C, Mitchell R, 1970. Kaposi's sarcoma in east African children: a report of 51 cases. J Pathol 100: 187-199.

10. Itakura $H$, Toriyama $K$, Uzuta $F, 1986$. Kaposi's sarcoma, pathology and local epidemiology in Kenya. Trop Med 28 (suppl): 3-8. 